\title{
Evaluation of the Mediterranean Diet Quality Index (KIDMED) in children and adolescents in Southern Spain
}

\author{
Miguel Mariscal-Arcas ${ }^{1}$, Ana Rivas ${ }^{1}$, Javier Velasco ${ }^{1}$, Maria Ortega ${ }^{1}$, Ascension Maria \\ Caballero ${ }^{2}$ and Fatima Olea-Serrano ${ }^{1, *}$ \\ 'Department of Nutrition and Food Science, University of Granada, Campus de Cartuja s/n, 18071 Granada, \\ Spain: ${ }^{2}$ Concejalia de Salud, Excmo, Ayuntamiento de Granada, Spain
}

Submitted 27 March 2008: Accepted 13 October 2008: First published online 17 December 2008

\begin{abstract}
Objective: The Mediterranean diet is considered one of the healthiest dietary models. Recent changes in the actual Mediterranean diet include a reduction in energy intake and a higher consumption of foods with low nutrient density (e.g. soft drinks, candy, sweets, etc.). In Spain, in association with cultural and lifestyle changes, there has been a reduction in the intake of antioxidants and vitamins, an increase in the proportion of SFA and a decrease in the consumption of fibre, among other changes. Children and adolescents may be the age groups with the most deteriorated Mediterranean diet. The current paper presents the results of applying the Mediterranean Diet Quality Index for children and adolescents (KIDMED) to a large sample of Spanish schoolchildren.

Design: Data from questionnaires were used to calculate the KIDMED index.

Setting: Granada, Southern Spain.

Subjects: Schoolchildren ( $n$ 3190) aged 8-16 years.

Results: Among the 8-10-year-olds, the KIDMED index classification was 'good' in $48.6 \%$ of the population, 'average' in $49.5 \%$ and 'poor' in $1.6 \%$. Among the 10-16-year-olds, the KIDMED index classification was good in $46.9 \%$ of the population, average in $51 \cdot 1 \%$ and poor in $2 \cdot 0 \%$.

Conclusions: The nutritional behaviour of the present population of schoolchildren is similar to that found in the earlier KIDMED study.
\end{abstract}



Keywords

Diet quality

Young people's diet

Southern Spain
The Mediterranean diet is considered one of the healthiest dietary models, and numerous epidemiological and nutritional studies have shown that Mediterranean countries benefit from lower rates of chronic disease morbidity and higher life expectancy. Thus, the traditional Mediterranean diet protects against myocardial infarction, some tumours (e.g. breast, colorectal and prostate), diabetes and other diseases associated with oxidative stress ${ }^{(1-6)}$. It may also contribute to reducing some disease complications, e.g. onset of a second myocardial infarction, risk of coronary heart surgery failure and diabetic vascular complications ${ }^{(7-9)}$.

Although the Mediterranean basin covers several different regions, all of their diets share common characteristics, including a central role for olive oil. Olive oil is not only beneficial for health but also associated with the consumption of large amounts of vegetables in salad and legumes and other cooked foods ${ }^{(10)}$. Fats represent approximately $30-40 \%$ of the daily energy intake, depending on the country in question ${ }^{(7)}$. The differential characteristics of the Mediterranean diet have been described by Keys ${ }^{(11)}$, although societal changes have led to varied levels of adherence to the Mediterranean diet in different countries. Studies have repeatedly demonstrated medium levels of adherence to this diet in Spain, at around 50\% of theoretical values $^{(12-14)}$. The influence of region on diet quality highlights the importance of considering regional nutrition strategies ${ }^{(15,16)}$. Thus, a reduction in diet quality in Portuguese households was associated with a deviation from the traditional Mediterranean diet and a lower compliance with WHO dietary goals. Recent changes in the actual Mediterranean diet include a reduction in energy intake and a higher consumption of foods with low nutrient density (e.g. soft drinks, candy, sweets, etc.). In Spain, in association with cultural and lifestyle changes, there has been a reduction in the intake of antioxidants and vitamins, an increase in the proportion of SFA, and a decrease in the consumption of fibre, among other changes ${ }^{(17)}$.

Children and adolescents may be the age groups with the most deteriorated Mediterranean diet profile, and there is a need for nutrition education programmes to establish healthy eating habits at a young age that will have beneficial effects in later life ${ }^{(18)}$. Both epidemiological and metabolic studies suggest that individuals can benefit greatly by adopting elements of Mediterranean diets ${ }^{(19)}$.

This paper presents the results of applying the Mediterranean Diet Quality Index for children and adolescents 
(KIDMED), developed by Serra-Majem et $a l^{(12,20)}$, to a large sample of schoolchildren in Southern Spain.

\section{Material and methods}

The sample comprised 3190 schoolchildren from Granada in Southern Spain, aged 8-16 years (mean $10 \cdot 8$ years; SD 1.8 years). Participating schools were randomly selected, each from a different neighbourhood of the city of Granada. Experienced and specifically trained interviewers administered each participant with a semi-quantitative FFQ, a $24 \mathrm{~h}$ recall, and a questionnaire on lifestyle and food habits ${ }^{(14,21-23)}$. Data from these questionnaires were used to calculate the KIDMED index of sixteen items, twelve of which are positively scored and four negatively scored ${ }^{(12,20)}$. Total KIDMED scores were classified as follows: $\geq 8$ points, good (optimal Mediterranean diet); 4-7 points, average; and $\leq 3$ points, poor.

Study age ranges were selected according to FAO/ $\mathrm{WHO}^{(24)}$. Other study variables were as follows: school type (public/private), number of inhabitants in the neighbourhood of the school, number of inhabitants between 5 and 19 years and number of male and female inhabitants (Table 1). The present study was approved by the Ethics Committee of our institution.

The SPSS for Windows statistical software package version $15 \cdot 0$ (SPSS Inc., Chicago, IL, USA) was used to analyse the data, applying ANOVA tests and Student's $t$-test. $P<0 \cdot 05$ was considered significant.

\section{Results}

Table 2 shows mean values of nutrients and ANOVA results as a function of age and sex. The validity of the questionnaire was tested by comparing the energy, protein, lipid and carbohydrate values estimated in the $24 \mathrm{~h}$ recall with the values obtained in the semi-quantitative FFQ, using the Spearman test. Rho values found were 0.690 for proteins, 0.830 for lipids and 0.785 for carbohydrates, with $P<0.05$ in all cases.

A descriptive analysis was performed of KIDMED levels as a function of age group ( $<10$ and $\geq 10$ years) and sex, and results were compared with findings of the EnKid Spain-wide study ${ }^{(20)}$ (see Table 2).

Table 2 shows the KIDMED index results by age and gender and the comparison with findings obtained for the whole of Spain in the EnKid survey by Serra-Majem et al. ${ }^{(20)}$, for similar age ranges. Among the 8-10-year-olds, the KIDMED index classification was 'good' in $48.6 \%$ of the population, 'average' in $49.5 \%$ and 'poor' in $1.6 \%$. The boys showed a higher percentage $(2 \cdot 4 \%)$ of poor index scores $v$. the girls, while the girls had a higher percentage $(53 \cdot 1 \%)$ of good scores. These gender differences were statistically significant $(P=0 \cdot 001)$. The mean score for the $8-10$-yearold population was 7.4 (SD 1-6). Among the 10-16-yearolds, the KIDMED index classification was good in $46.9 \%$ of the population, average in $51.1 \%$ and poor in $2.0 \%$. The boys showed higher percentages of poor $(2 \cdot 3 \%)$ and good $(47 \cdot 1 \%)$ scores $v$. the girls, while the girls had a higher percentage of average scores (51.3\%). In this older age group, these gender differences did not reach statistical significance $(P=0 \cdot 806)$. The mean score for this age group was $7 \cdot 3$ (SD 1.6). Around half of both age groups had an 'average' KIDMED score (4-7) (Table 2).

As shown in Table 1, significant differences in index scores were observed as a function of the school type $(P<0 \cdot 001)$ and of the total number of inhabitants $(P=$ $0 \cdot 040)$ and number of male $(P=0.043)$ and female $(P=0 \cdot 041)$ inhabitants in the neighbourhood of the school.

Table 1 Percentage of the study population with different KIDMED classifications as a function of school and district characteristics

\begin{tabular}{|c|c|c|c|c|}
\hline & Poor $(\leq 3)$ & Average (4-7) & Good $(\geq 8)$ & $P^{*}$ \\
\hline \multicolumn{5}{|l|}{ School type } \\
\hline State $(n$ 1259) & $1 \cdot 4$ & $47 \cdot 9$ & $50 \cdot 7$ & \multirow[t]{2}{*}{0.001} \\
\hline Private $(n$ 1931) & $2 \cdot 2$ & $52 \cdot 5$ & $45 \cdot 3$ & \\
\hline \multicolumn{5}{|l|}{ Number of inhabitants } \\
\hline$<26000(n 1155)$ & $2 \cdot 0$ & $51 \cdot 3$ & $46 \cdot 8$ & \multirow[t]{3}{*}{$0 \cdot 040$} \\
\hline $26000-30000(n 998)$ & $1 \cdot 8$ & $48 \cdot 5$ & $49 \cdot 7$ & \\
\hline$>30000(n 1037)$ & $1 \cdot 9$ & $52 \cdot 1$ & $46 \cdot 0$ & \\
\hline \multicolumn{5}{|l|}{ Population 5-19 years } \\
\hline$<4000(n$ 1541) & 1.9 & $50 \cdot 6$ & $47 \cdot 5$ & \multirow[t]{3}{*}{0.087} \\
\hline $4000-5500$ (n 612) & $1 \cdot 8$ & $48 \cdot 5$ & $49 \cdot 7$ & \\
\hline$>5500(n 1037)$ & $1 \cdot 9$ & $52 \cdot 1$ & $46 \cdot 0$ & \\
\hline \multicolumn{5}{|l|}{ Male populationt } \\
\hline$<12000(n 1155)$ & $2 \cdot 0$ & $51 \cdot 3$ & $46 \cdot 8$ & \multirow[t]{3}{*}{0.043} \\
\hline $12000-14000$ (n 998) & $1 \cdot 8$ & $48 \cdot 5$ & $49 \cdot 7$ & \\
\hline$>14000(n 1037)$ & $1 \cdot 9$ & $52 \cdot 1$ & $46 \cdot 0$ & \\
\hline \multicolumn{5}{|l|}{ Female populationt } \\
\hline$<14000(n 1155)$ & $2 \cdot 0$ & $51 \cdot 3$ & $46 \cdot 8$ & \multirow[t]{3}{*}{0.041} \\
\hline $14000-16000$ (n 998) & $1 \cdot 8$ & $48 \cdot 5$ & $49 \cdot 7$ & \\
\hline$>16000(n 1037)$ & $1 \cdot 9$ & $52 \cdot 1$ & $46 \cdot 0$ & \\
\hline
\end{tabular}

*Student's $t$-test for school type and ANOVA for remaining variables.

tPopulation categorized by the total population (males and females) in each district (city census). 


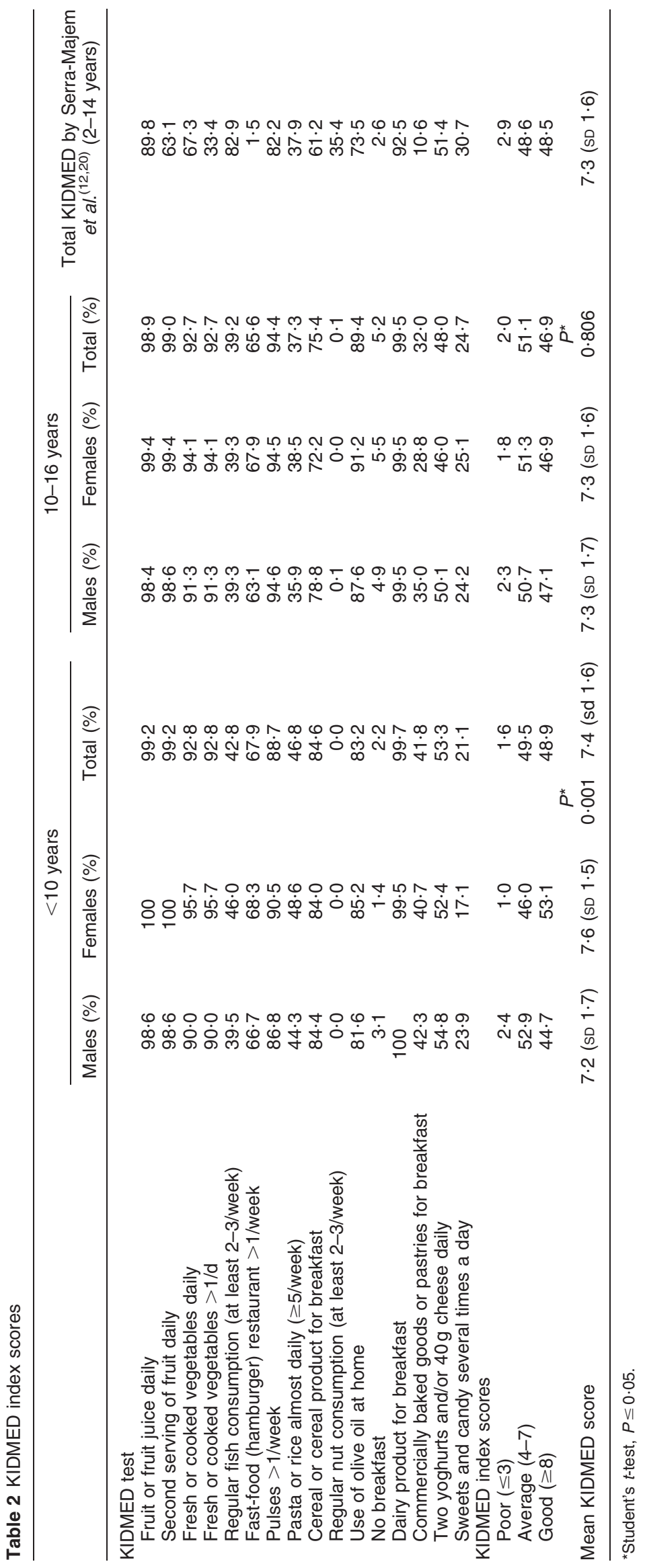




\section{Discussion}

The mean energy intake of the present study population was higher than the mean theoretical energy expenditure calculated using equations proposed for these ages by the $\mathrm{FAO} / \mathrm{WHO} / \mathrm{UNU}^{(24)}$. Their protein intake was more than double recommended levels, as reported in other Spanish studies $^{(25,26)}$ and consistent with the general trend in the Spanish population to consume large amounts of meat and meat derivatives. The lipid intake of this group was higher than that observed in studies in Northwest Spain and Australia ${ }^{(27,28)}$. Their energy profile was clearly imbalanced, with a high percentage of energy from proteins and lipids and a low proportion from carbohydrates, a characteristic situation in Mediterranean countries ${ }^{(29,30)}$. It is recommended that lipids should supply less than $35 \%$ of the total energy in the diet ${ }^{(31)}$. The percentage of energy contributed by fatty acids was also imbalanced, as found in numerous countries $^{(29,32,33)}$. The intake of mineral salts differed significantly $(P<0 \cdot 01)$ from recommendations, and only the children $(<10$ years) met the RDI for calcium. There appears to be a relationship between a low-Ca diet and a deficiency in other micronutrients ${ }^{(34)}$, and an adequate Ca intake during initial stages of life is critical to achieving an optimal bone mass peak ${ }^{(35,36)}$. The RDI for Fe intake was fully met by the children but not by the male or female adolescents. Iodine intake was lower than the RDI in all three groups, possibly due to their low consumption of fish, fruit and vegetables ${ }^{(37)}$. Among the vitamins studied, only vitamin $\mathrm{E}$ intake was below the daily recommendations for this population, as found in other Spanish studies ${ }^{(38,39)}$.

The KIDMED Diet Quality Index ${ }^{(20)}$, which evaluates adherence to an optimum traditional Mediterranean diet, was applied to 3190 schoolchildren from Granada in Southern Spain. The mean index score of this 8-16-yearold population was $7 \cdot 33$ (SD 1.63) points, classified as 'average-good' by the authors. Slightly better scores were obtained by the under-10-year-olds than by the children aged 10 years and older. Among the under-10-year-olds, the index score was significantly higher $(P<0 \cdot 001)$ for the girls than for the boys. In comparison with the KIDMED results obtained by Serra-Majem et al. ${ }^{(20)}$ for children aged 2-14 years, the two populations reported practically identical percentages of pasta, rice, breakfast milk products, yoghurt and cheeses, and similar percentages of fruit, juices, pulses, desserts and sweets. However, a higher proportion of the present population consumed a second piece of fruit, cereals, cereal products and vegetables, while the percentage consuming fish $2 / 3$ times weekly was almost half that in the study by Serra-Majem et al. ${ }^{(20)}$. The frequency of visits to fast food establishments was considerably higher than that reported by the children in the earlier study ${ }^{(20)}$. The intake of nuts was reported by virtually none of the present children compared with $35.4 \%$ in the reference study ${ }^{(20)}$. A mean of $>85 \%$ of the Granada population used olive oil compared with $73.5 \%$ in the reference population, consistent with other findings in southern Spain, a major producer of olive oil, where it is firmly embedded in sociocultural traditions. Thus, the mean individual consumption of oil in this region $(56 \mathrm{~g} / \mathrm{d})$ is $6 \%$ higher than in the rest of Spain $(52 \mathrm{~g} / \mathrm{d})^{(31)}$. Numerous researchers have described the benefits of consuming olive oil for its high MUFA and antioxidant content ${ }^{(40,41)}$. Besides olive oil, wine also contributes to the intake of antioxidants in the Mediterranean diet $^{(42)}$ but is not expected to be consumed by children and is therefore not included in the KIDMED survey.

Less than $2.5 \%$ of the children from either private or state schools had a poor KIDMED score, with around half of each population classified with a score between average and good. ANOVA test results showed a significant difference in the distribution of poor, average and good scores as a function of the number of inhabitants and of male and female inhabitants (Table 1).

In conclusion, the nutritional behaviour of the present population of schoolchildren is similar to that found in the earlier KIDMED study. Discrepancies can be attributed to their inclusion of a younger age group.

\section{Acknowledgements}

Conflict of interest: The authors declare that they have no conflicts of interest.

Funding support: The study was supported by grants from the Concejalia de Salud del Excmo, Ayuntamiento de Granada, Spain.

Authors' contributions: The following contributions were made by each author: M.M.-A. - study design, statistical treatment and redaction of article. A.R. - study design, statistical treatment and redaction of article. J.V. data collection and development of database. M.O. - data collection and treatment. A.M.C. - data collection and collaboration with institutions. F.O.-S. - study design and coordination and redaction of article.

Acknowledgements: The authors wish to thank Richard Davies for his assistance with the English version.

\section{References}

1. Panagiotakos DB, Pitsavos C, Chrysohoou C, Stefanadis C \& Toutouzas P (2002) The role of traditional Mediterranean-type of diet and lifestyle, in the development of acute coronary syndromes: preliminary results from CARDIO2000 study. Cent Eur J Public Health 10, 11-15.

2. Pitsavos C, Panagiotakos DB, Chrysohoou C, Skoumas J, Papaioannou I, Stefanadis C \& Toutouzas PK (2002) The effect of Mediterranean diet on the risk of the development of acute coronary syndromes in hypercholesterolemic people: a casecontrol study (CARDIO2000). Coron Artery Dis 13, 295-300.

3. Pitsavos C, Panagiotakos DB, Chrysohoou C, Papaioannou I, Papadimitriou L, Tousoulis D, Stefanadis C \& Toutouzas P (2003) The adoption of Mediterranean diet attenuates the development of acute coronary syndromes in people with the metabolic syndrome. Nutr J 3, 9.

4. Trichopoulou A, Costacou T, Bamia C \& Trichopoulos D (2003) Adherence to a Mediterranean diet and survival in a Greek population. N Engl J Med 348, 2599-2608. 
5. Martinez-Gonzalez MA, Fernandez-Jarne E, Serrano-Martinez M, Marti A, Martinez JA \& Martin-Moreno JM (2002) Mediterranean diet and reduction in the risk of a first acute myocardial infarction: an operational healthy dietary score. Eur J Nutr 41, 153-160.

6. Giugliano D \& Esposito K (2008) Mediterranean diet and metabolic diseases. Curr Opin Lipidol 19, 63-68.

7. Trichopoulou A \& Lagiou P (1997) Healthy traditional Mediterranean diet: an expression of culture, history, and lifestyle. Nutr Rev 55, 383-389.

8. Willett WC, Sacks F, Trichopoulou A, Drescher G, FerroLuzzi A, Helsing E \& Trichopoulos D (1995) Mediterranean diet pyramid: a cultural model for healthy eating. Am J Clin Nutr 61, Suppl. 6, 1402S-1406S.

9. Serra-Majem L (2001) ¿Más beneficios de la dieta mediterránea? Nutr Obesidad 4, 43-46.

10. Trichopoulou A (2001) Mediterranean diet: the past and the present. Nutr Metab Cardiovasc Dis 11, 4 Suppl., 1-4.

11. Keys A (1995) Mediterranean diet and public health: personal reflections. Am J Clin Nutr 61, Suppl. 6, 1321S-1323S.

12. Serra-Majem L, Ribas L, García A, Pérez-Rodrigo C \& Aranceta J (2003) Nutrient adequacy and Mediterranean Diet in Spanish school children and adolescents. Eur J Clin Nutr 57, Suppl. 1, S35-S39.

13. Tur JA, Romaguera D \& Pons A (2004) Adherence to the Mediterranean dietary pattern among the Balearic Islands population. Br J Nutr $92,341-346$.

14. Mariscal-Arcas M, Romaguera D, Rivas A, Feriche B, Pons A, Tur JA \& Olea-Serrano F (2007) Diet quality of young people in southern Spain evaluated by a Mediterranean adaptation of the Diet Quality Index-International (DQI-I). Br J Nutr 98, 1267-1273.

15. Rodrigues SS, Caraher M, Trichopoulou A \& de Almeida MD (2007) Portuguese households' diet quality (adherence to Mediterranean food pattern and compliance with WHO population dietary goals): trends, regional disparities and socioeconomic determinants. Eur J Clin Nutr 62, 1263-1272.

16. Chen Q \& Marques-Vidal P (2007) Trends in food availability in Portugal in 1966-2003 comparison with other Mediterranean countries. Eur J Nutr 46, 418-427.

17. Serra-Majem L \& Ribas L (1995) Habitos alimentarios y consumo de alimentos en España. Dieta mediterra'nea. In Nutricion y Salud Publica. Métodos, Bases Cientificas y Aplicaciones [L Serra-Majem, J Aranceta and J Mataix, editors]. Barcelona: Masson.

18. Serra-Majem L, Aranceta Bartrina J, Ribas Barba L, Perez Rodrigo C \& García Closas R (2000) Estudio EnKid: objetivos y metodología. In Desayuno y Equilibrio Alimentario. Estudio EnKid [L Serra-Majem and J Aranceta, editors]. Barcelona: Masson.

19. Willett WC (2006) The Mediterranean diet: science and practice. Public Health Nutr 9, 105-110.

20. Serra-Majem L, Ribas L, Ngo J, Ortega RM, Garcia A, PerezRodrigo C \& Aranceta J (2004) Food, youth and the Mediterranean diet in Spain. Development of KIDMED, Mediterranean Diet Quality Index in children and adolescents. Public Health Nutr 7, 931-935.

21. Mariscal M (2006) Nutrition and Physical Activity in Spanish Children and Adolescents. Granada: University of Granada.

22. Rivas A, Cerrillo I, Granada A, Mariscal-Arcas M \& OleaSerrano F (2007) Pesticide exposure of two age groups of women and its relationship with their diet. Sci Total Environ 382, 14-21.

23. Velasco J (2008). Estudio nutricional en los escolares de Granada. Granada: University of Granada.

24. Food and Agriculture Organization of the United Nations/ World Health Organization/United Nations University (2004) Human Energy Requirements. Report of a Joint FAO/WHO/UNU Expert Consultation. Rome: FAO.
25. Serra LL, Ribas L, Pérez C, Roman B \& Aranceta J (2003) Hábitos alimentarios y consumo de alimentos en la población infantil y juvenil española (1998-2000): variables socioeconómicas y geográficas. Med Clín 121, 126-131.

26. Barquera S, Rivera JA, Safdie M, Flores M, Campos-Nonato I \& Ca F (2003) Energy and nutrient intake in preschool and school age Mexico children: National Nutrition Survey. Salud Pública México 45, Suppl. 4, 540S-550S.

27. Tojo R \& Leis R (2000). Nutrition among children and adolescent in Galicia. The Galinut study. In Decalogue of on Diet in the 21st Century [G Varela, editor]. Spain: Fundación Española de Nutrición.

28. O'Connor J, Ball EJ, Steinbeck KS, Davies PSW, Wishart C, Gaskin KJ et al. (2001) Comparison of total energy expenditure and energy intake in children aged 6-9 years. Am J Clin Nutr 74, 643-649.

29. Moreno LA, Sarria A \& Popkin BM (2002) The nutrition transition in Spain: a European Mediterranean country. Eur J Clin Nutr 56, 992-1003.

30. Mena MC, Faci M, Ruch AL, Aparicio A, Lozano Estevan MC \& Ortega Anta RM (2002) Diferencias en los hábitos alimentarios y conocimientos, respecto a las características de una dieta equilibrada en jóvenes con diferente índice de masa corporal. Rev Esp Nutr Comun 8, 19-23.

31. SENC (2001) Guías alimentarias para la población española: recomendaciones para una dieta saludable. Madrid: IM\&C.

32. Aeberli I, Kaspar M \& Zimmermann MB (2007) Dietary intake and physical activity of normal weight and overweight 6 to 14-year-old Swiss children. Swiss Med Wkly 137, 424-430.

33. Hanning RM, Woodruff SJ, Lambraki I, Jessup L, Driezen P \& Murphy CC (2007) Nutrient intakes and food consumption patterns among Ontario students in grades six, seven, and eight. Can J Public Health 98, 12-16.

34. New SA, Robins SP, Campbell MK, Martin JC, Garton MJ \& Bolton-Smith C (2000) Dietary influences on bone mass and bone metabolism: further evidence of a positive link between fruit and vegetable consumption and bone health. Am J Clin Nutr 71, 142-151.

35. Ortega RM \& Povea FI (2000) Estudio dietético. In Nutriguia [AM Requejo and RM Ortega, editors]. Madrid: Complutense.

36. Wosje KS \& Specker BL (2000) Role of calcium in bone health during childhood. Nutr Rev 58, 253-268.

37. Chrysohoou C, Panagiotakos DB, Pitsavos C, Skoumas J, Krinos X, Chloptsios Y, Nikolaou V \& Stefanadis C (2007) Long-term fish consumption is associated with protection against arrhythmia in healthy persons in a Mediterranean region - the ATTICA study. Am J Clin Nutr 85, 1385-1391.

38. Ortega RM, Mena MC, Faci M, Santana JF \& Serra-Majem L (2001) Vitamin status in different groups of the Spanish population: a meta-analysis of national studies performed between 1990 and 1999. Public Health Nutr 4, 1325-1329.

39. Tur JA, Serra-Majem L, Romaguera D \& Pons A (2005) Does the diet of the Balearic population, a Mediterranean type diet, still provide adequate antioxidant nutrient intakes? Eur J Nutr 44, 204-213.

40. Trichopoulou A \& Dilis V (2007) Olive oil and longevity. Mol Nutr Food Res 51, 1275-1278.

41. Waterman E \& Lockwood B (2007) Active components and clinical applications of olive oil. Altern Med Rev 12, 331-342.

42. Papamichael CM, Karatzi KN, Papaioannou TG, Karatzis EN, Katsichti P, Sideris V, Zakopoulos N, Zampelas A \& Lekakis JP (2008) Acute combined effects of olive oil and wine on pressure wave reflections: another beneficial influence of the Mediterranean diet antioxidants? J Hypertens 26, 223-229. 